\title{
A study on the survey for actual condition of local junior col- lege graduates in Japan
}

\section{Toru Sugihara *}

\begin{abstract}
In this study, the following three things became clear by analyzing the results of a survey conducted among the graduates of a Junior College in Japan. Firstly, there is a difference between students who ask for advice from teachers and students who do not. It was found that the former students have a higher expectation for the college and higher motivation. This result shows us that going to professors for advice gives students good effects improved on their school lives. Secondly, there is a difference between students who have any achieved certificates and students who do not. It was found that the former students think to keep pursue learning even after graduation. It is considered that those students are strongly aware of the necessity to pursue their future careers or the importance of learning by pursuing certificates. Thirdly, the method of entrance to the university does not make any difference to students. Perhaps this means the students who pursue their careers gain satisfaction from their school lives, and can keep learning after graduation.
\end{abstract}

Keywords: Graduate Research; Institutional Research; Counseling; Certification

\section{Introduction}

Recently, many universities in Japan have established IR (Institutional Research) departments. This movement began in United States universities. Institutional Research is research conducted within an institution of higher education to provide information that supports institutional planning, policy formation and decision making [1]. An Institutional Research survey was conducted in Japan. In this survey, learning evaluation is classified into two ways. There are direct measures and indirect measures. Direct measures are such things as examination, report, graduation thesis. Indirect measures are questionnaire, interview etc. Student survey is an indirect measurement [2].

\section{Purpose and method}

As the background of the survey, information disclosure of the University is required. A graduate survey has been conducted as a student survey. So, I proposed planning a college students graduate survey.

\footnotetext{
* Kanto Gakuin University, Yokohama, Japan
} 
The study was carried out at the local junior college (X junior college) as follows. There are three programs in the junior college: school nurse, nutritionist, nursery and kindergarten teacher.

Date: 2013/2/15 Object: junior college sophomore (graduates)

Number: 121 people Survey method: questionnaire survey

I referred to the question items for junior college students that Kawamata has created[3]. Question items are "college-going motivation", "expectation for the university", "tuition and living expenses", "certification", "effect of learning", "program after graduation", "the need to learn after graduation", "participation in events".

Figure 1 shows the survey range in this study. I analyzed college students and reported to management. But I didn't act to education, administration, or social activity departments.

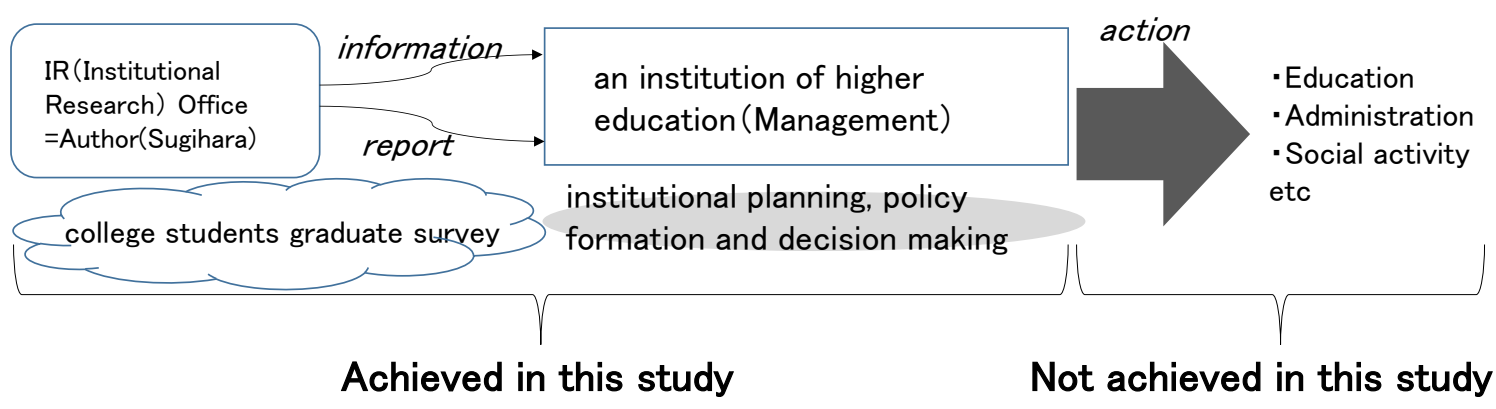

Figure1.the study range

I analyzed the three programs (school nurse program, nutritionist program, nursery and kindergarten teacher program) of $\mathrm{X}$ junior college.

The results of the analysis are described in Tables 1,2,3,4. There were some differences in college-going motivation and satisfaction. Table 1 shows the analysis of college-going motivation. So, Major is high in all programs (about 70\%). But for passing certifications, and recommendation of high school teacher, the nutritionist program and the nursery and kindergarten teacher program are higher than school nurse program. Tables 2,3, and 4 show university satisfaction (Table3: Lesson, Table4: Teacher). For Table2.3.4, nutritionist program and nursery and kindergarten teacher program have higher satisfaction than the school nurse program. One probable cause of this result may be taking the certification exam. Most of the students (nutritionist program and nursery and kindergarten teacher program) take the certification. But it is difficult to achieve the school nurse certification, so only half the students take this certification exam. And there are students who do not have the goal of taking the certification. In addition, I considered the following Research Questions. 
Table1. Why did you go to university?

\begin{tabular}{|c|c|c|c|c|c|c|c|c|c|}
\hline \multirow{2}{*}{\multicolumn{2}{|c|}{ Q5 Why did you go to university? (plural marking) }} & \multicolumn{2}{|c|}{$\begin{array}{l}\text { school nurse } \\
\text { program }\end{array}$} & \multicolumn{2}{|c|}{ nutritionist program } & \multicolumn{2}{|c|}{$\begin{array}{c}\text { nursery and } \\
\text { kindergarten } \\
\text { teacher program }\end{array}$} & \multicolumn{2}{|c|}{ total } \\
\hline & & number & $\begin{array}{l}\text { percenta } \\
\text { ge }\end{array}$ & number & $\begin{array}{l}\text { percenta } \\
\text { ge }\end{array}$ & number & $\begin{array}{l}\text { percenta } \\
\text { ge }\end{array}$ & number & $\begin{array}{l}\text { percenta } \\
\text { ge }\end{array}$ \\
\hline 1 & There was a major I wanted to learn & 66 & $76: 2 \%$ & 27 & $7 \mathrm{t} \%$ & 46 & $742^{\circ}$ & 89 & $736 \%$ \\
\hline 2 & take certifications & 9 & $42.9 \%$ & 29 & $763 \%$ & 41 & $66 \%$ & 79 & $65.3 \%$ \\
\hline 3 & finding employment & 3 & $14.3 \%$ & 4 & $10.5 \%$ & 13 & $21.0 \%$ & 20 & $16.5 \%$ \\
\hline 4 & school spirit & 3 & $14.3 \%$ & 4 & $10.5 \%$ & 6 & $9.7 \%$ & 13 & $10.7 \%$ \\
\hline 5 & attending school & 5 & $23.8 \%$ & 8 & $21.1 \%$ & 16 & $25.8 \%$ & 29 & $24.0 \%$ \\
\hline 6 & recommendation of high school teacher & 1 & $4.8 \%$ & 5 & $32^{2 \%}$ & 16 & 2580 & 22 & $18.2 \%$ \\
\hline 7 & recommendation of parent & 3 & $14.3 \%$ & 3 & $7.9 \%$ & 6 & $9.7 \%$ & 12 & $9.9 \%$ \\
\hline 8 & recommendation of friends & 0 & $0.0 \%$ & 0 & $0.0 \%$ & 3 & $4.8 \%$ & 3 & $2.5 \%$ \\
\hline 9 & academic achievement & 3 & $14.3 \%$ & 4 & $10.5 \%$ & 5 & $8.1 \%$ & 12 & $9.9 \%$ \\
\hline 10 & economic reasons & 2 & $9.5 \%$ & 4 & $10.5 \%$ & 1 & $1.6 \%$ & 7 & $5.8 \%$ \\
\hline 11 & I did not go to the school I want to go to & 1 & $4.8 \%$ & 4 & $10.5 \%$ & 2 & $3.2 \%$ & 7 & $5.8 \%$ \\
\hline 12 & education philosophy & 1 & $4.8 \%$ & 0 & $0.0 \%$ & 1 & $1.6 \%$ & 2 & $1.7 \%$ \\
\hline 13 & others & 2 & $9.5 \%$ & 0 & $0.0 \%$ & 0 & $0.0 \%$ & 2 & $1.7 \%$ \\
\hline
\end{tabular}

Table2. How well were you satisfied? (University)

\begin{tabular}{|c|c|c|c|c|c|c|c|c|c|}
\hline & & \multicolumn{2}{|c|}{$\begin{array}{l}\text { school nurse } \\
\text { program }\end{array}$} & \multicolumn{2}{|c|}{ nutritionist program } & \multicolumn{2}{|c|}{$\begin{array}{c}\text { nursery and } \\
\text { kindergarten } \\
\text { teacher program }\end{array}$} & \multicolumn{2}{|c|}{ total } \\
\hline & Q7 How long did you satisfied? (University) & number & \begin{tabular}{|l|} 
percenta \\
ge
\end{tabular} & number & \begin{tabular}{|l|} 
percenta \\
ge
\end{tabular} & number & \begin{tabular}{|l||} 
percenta \\
ge
\end{tabular} & number & $\begin{array}{l}\text { percenta } \\
\text { ge }\end{array}$ \\
\hline 5 & Very satisfied & 1 & $4.8 \%$ & 4 & $10: 5 \%$ & 5 & $24: 2 \%$ & 20 & $16.5 \%$ \\
\hline 4 & Quite a satisfied & 6 & $28.6 \%$ & $16:$ & $421 \%$ & 32 & $516 \%$ & 54 & $44.6 \%$ \\
\hline 3 & ordinary & 10 & $47.6 \%$ & 17 & $44.7 \%$ & 14 & $22.6 \%$ & 41 & $33.9 \%$ \\
\hline 2 & Little satisfied & 3 & $14.3 \%$ & 1 & $2.6 \%$ & 0 & $0.0 \%$ & 4 & $3.3 \%$ \\
\hline & Never satisfied & 1 & $4.8 \%$ & 0 & $0.0 \%$ & 1 & $1.6 \%$ & 2 & $1.7 \%$ \\
\hline & total & 21 & $100.0 \%$ & 38 & $100.0 \%$ & 62 & $100.0 \%$ & 121 & $100.0 \%$ \\
\hline
\end{tabular}

Table3. How well were you satisfied? (Lesson)

\begin{tabular}{|c|c|c|c|c|c|c|c|c|c|}
\hline & & \multicolumn{2}{|c|}{$\begin{array}{l}\text { school nurse } \\
\text { program }\end{array}$} & \multicolumn{2}{|c|}{ nutritionist program } & \multicolumn{2}{|c|}{$\begin{array}{c}\text { nursery and } \\
\text { kindergarten } \\
\text { teacher program }\end{array}$} & \multicolumn{2}{|c|}{ total } \\
\hline & Q7 How long did you satisfied? (Lesson) & number & $\begin{array}{l}\text { percenta } \\
\text { ge }\end{array}$ & number & \begin{tabular}{|l|} 
percenta \\
ge
\end{tabular} & number & \begin{tabular}{|l|}
$\begin{array}{l}\text { percenta } \\
\text { ge }\end{array}$ \\
\end{tabular} & number & $\begin{array}{l}\text { percenta } \\
\text { ge }\end{array}$ \\
\hline 5 & Very satisfied & 2 & $9.5 \%$ & 6 & $158 \%$ & 19 & $30.6 \%$ & 27 & $22.3 \%$ \\
\hline 4 & Quite a satisfied & 8 & $38.1 \%$ & 20 & $5266 \%$ & 32 & $516 \%$ & 60 & $49.6 \%$ \\
\hline 3 & ordinary & 8 & $38.1 \%$ & 12 & $31.6 \%$ & 10 & $16.1 \%$ & 30 & $24.8 \%$ \\
\hline 2 & Little satisfied & 2 & $9.5 \%$ & 0 & $0.0 \%$ & 1 & $1.6 \%$ & 3 & $2.5 \%$ \\
\hline & Never satisfied & 1 & $4.8 \%$ & 0 & $0.0 \%$ & 0 & $0.0 \%$ & 1 & $0.8 \%$ \\
\hline & total & 21 & $100.0 \%$ & 38 & $100.0 \%$ & 62 & $100.0 \%$ & 121 & $100.0 \%$ \\
\hline
\end{tabular}

Table4. How well were you satisfied? (Teacher)

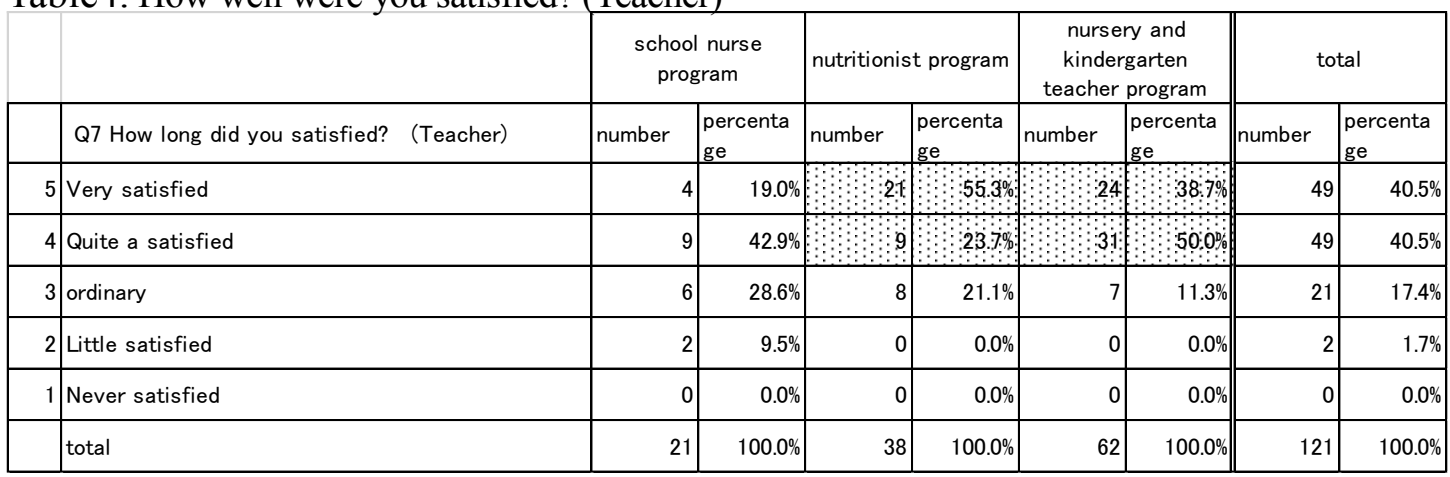




\section{Research Question}

I discussed Research Question with X junior college department chair. We shared the problems of X junior college. Taking this matter into account, I made and verified five Research Questions (RQ).

【RQ1】Is there a significant difference between students who asked for advice from professors and students who did not?

【RQ2】Is there a significant difference in the presence or absence of certification?

【RQ3】Is there a significant difference in the way to enter the university?

【RQ4】Is there a significant difference between first choice and the other (Not first choice) about going $\mathrm{X}$ junior college?

【RQ5】 Is there a significant difference between students who participated in club activities and students who did not?

\section{Results}

【RQ1】Is there a significant difference between students who asked for advice from professors and students who did not?

There are 4 choices at "Q12. Did you want to consult with the teacher about your work?". In order to test RQ1, "consulted many times" and "consulted sometimes consultation" in Q12 are referred to as 『Consultation group』. " a little consultation" and " no consultation" are referred to as 『Non Consultation group』.

I analyzed between Consultation group and Non Consultation group about Q7,Q10,Q13,Q14,Q15,Q16 by Mann-Whitney's U test. (“Q7. Satisfaction after admission" "Q10. Effect of learning in junior college" "Q13. After Junior College graduation, do you want to consult with the teacher about your work?" "Q14. After Junior College graduation, the need to learn" "Q15. After Junior College graduation, do you want to participate in school the events?" "Q16. Did you participate in club activities?") . There are 94 people in the Consultation group and 21 people in the Non Consultation group.

The results of the analysis are described in Table 5. There was a significant difference in the Q7,Q10,Q13,Q15,Q16. Consultation group is higher than Non Consultation group. (Q12. Did you want to consult with the teacher about your work?)

In detail, Consultation group is higher about "A .University $(\mathrm{p}<0.05)$ ", "C. Teacher $(\mathrm{p}<$ $0.01)$ ", "D. Career support $(\mathrm{p}<0.01)$ ", “E. Facility $(\mathrm{p}<0.05)$ " in Q7. And "A. Finding a satisfactory job $(\mathrm{p}<0.01)$ ", “ B. Long-term career $(\mathrm{p}<0.01)$ ", “ C. Human relationship building $(\mathrm{p}<0.05)$ ", “E. Character formation $(\mathrm{p}<0.05)$ ", "F. Acquisition of Liberal Arts $(\mathrm{p}$ $<0.01)$ " in Q10.

There was a significant difference in the Q16. However, Non Consultation group is higher than the Consultation group. 
Table5.【RQ1】 Is there a significant difference between students who ask for advice from professors and students who do not? ${ }^{* *} \mathrm{p}<0.01,{ }^{*} \mathrm{p}<0.05$

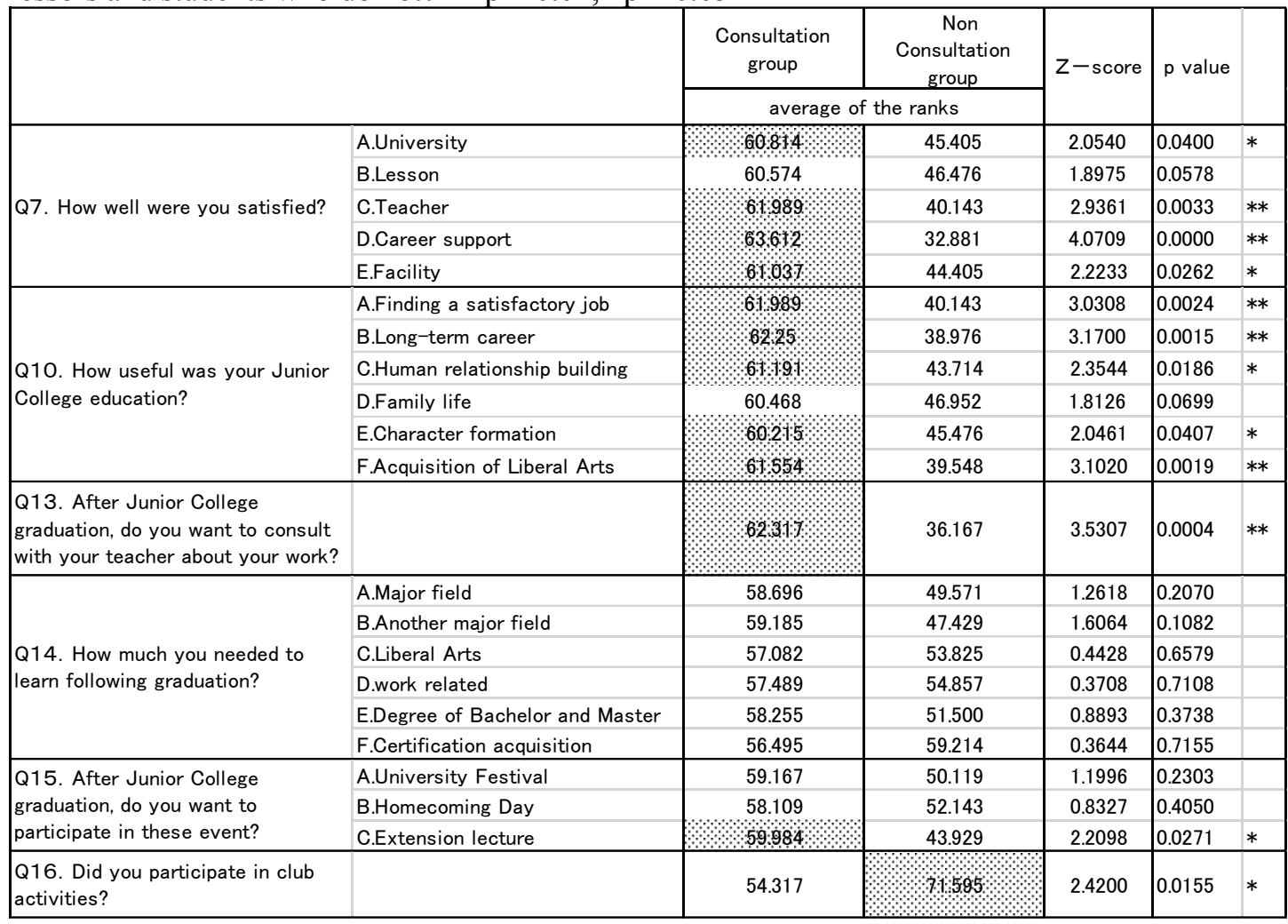

【RQ2】Is there a significant difference in the presence or absence of certification?

In order to test RQ2, students who took one or more of the four certifications (nutritionist, school nurse, nursery teacher, kindergarten teacher) are referred to as 『Certification group』. These certifications are important to employment. Students who didn't take certifications of nutritionist, school nurse, nursery teacher, kindergarten teacher are referred to as 『Not Certification group』.

I analyzed between Certification group and Not Certification group about Q7,Q10,Q13,Q14,Q15,Q16 by Mann-Whitney's U test. There are 105 people in the Certification group and 16 people in the Not Certification group

The results of the analysis are described in Table 6. There was a significant difference in the Q14. Certification group is higher than Not Certification group. In detail, Certification group is higher in "B. Another major field $(\mathrm{p}<0.01)$ ", "C. Liberal Arts $(\mathrm{p}<0.01)$ ", "D. work related $(\mathrm{p}<0.01)$ ", "F. Certification acquisition $(\mathrm{p}<0.05)$ " in Q14.

Table6.【RQ2】 Is there a significant difference in the presence or absence of certification? ${ }^{* *} \mathrm{p}<0.01,{ }^{*} \mathrm{p}<0.05$ 


\begin{tabular}{|c|c|c|c|c|c|c|}
\hline & & Certification group & $\begin{array}{c}\text { Not Certification } \\
\text { group }\end{array}$ & \multirow[t]{2}{*}{ Z-score } & \multirow[t]{2}{*}{$\mathrm{p}$ value } & \\
\hline & & \multicolumn{2}{|c|}{ average of the ranks } & & & \\
\hline \multirow{5}{*}{ Q7. How well were you satisfied? } & A.University & 61.029 & 60.813 & 0.0246 & 0.9803 & \\
\hline & B.Lesson & 61.538 & 57.469 & 0.4684 & 0.6395 & \\
\hline & C.Teacher & 62.757 & 49.469 & 1.5205 & 0.1284 & \\
\hline & D.Career support & 62.952 & 48.188 & 1.6702 & 0.0949 & \\
\hline & E.Facility & 60.405 & 64.906 & 0.5144 & 0.6070 & \\
\hline \multirow{6}{*}{$\begin{array}{l}\text { Q10. How useful was your Junior } \\
\text { College education? }\end{array}$} & A.Finding a satisfactory job & 61.571 & 57.250 & 0.5052 & 0.6134 & \\
\hline & B.Long-term career & 61.367 & 58.594 & 0.3227 & 0.7469 & \\
\hline & C.Human relationship building & 61.624 & 56.906 & 0.5406 & 0.5888 & \\
\hline & D.Family life & 62.662 & 50.094 & 1.4319 & 0.1522 & \\
\hline & E.Character formation & 60.938 & 57.656 & 0.3884 & 0.6977 & \\
\hline & F.Acquisition of Liberal Arts & 61.813 & 51.969 & 1.1782 & 0.2387 & \\
\hline $\begin{array}{l}\text { Q12. Did you consult with your } \\
\text { teacher about your work? }\end{array}$ & & 62.719 & 49.719 & 1.5081 & 0.1315 & \\
\hline $\begin{array}{l}\text { Q13. After Junior College } \\
\text { graduation, do you want to consult } \\
\text { with your teacher about your work? }\end{array}$ & & 60.367 & 61.433 & 0.1196 & 0.9048 & \\
\hline \multirow{6}{*}{$\begin{array}{l}\text { Q14. How much you needed to } \\
\text { learn following graduation? }\end{array}$} & A.Major field & 6527 & 23.400 & 4.8159 & 0.0000 & ** \\
\hline & B.Another major field & 6359 & 35.100 & 3.2292 & 0.0012 & ** \\
\hline & C.Liberal Arts & 6396 & 26.250 & 4.1964 & 0.0000 & ** \\
\hline & D.work related & 6297 & 39.367 & 2.7415 & 0.0061 & ** \\
\hline & E.Degree of Bachelor and Master & 61.572 & 49.100 & 1.3699 & 0.1707 & \\
\hline & F.Certification acquisition & 62712 & 41.200 & 2.3908 & 0.0168 & $*$ \\
\hline \multirow{3}{*}{$\begin{array}{l}\text { Q15. After Junior College } \\
\text { graduation, do you want to } \\
\text { participate in these event? }\end{array}$} & A.University Festival & 61.671 & 52.300 & 1.0341 & 0.3011 & \\
\hline & B.Homecoming Day & 61.274 & 51.167 & 1.1823 & 0.2371 & \\
\hline & C.Extension lecture & 61.192 & 51.733 & 1.0864 & 0.2773 & \\
\hline $\begin{array}{l}\text { Q16. Did you participate in club } \\
\text { activities? }\end{array}$ & & 58.443 & 74.900 & 1.9130 & 0.0557 & \\
\hline
\end{tabular}

【RQ3】Is there a significant difference in the way to enter the university?

In order to test RQ3, I classified the entrance examination method into four groups. These are: 『Recommendation entrance examination group』, 『Admissions Office entrance examination group』, 『Achievement entrance examination group』, 『Working people entrance examination group』.

I analyzed 4 groups in their answers to: Q7,Q10,Q12,Q13,Q14,Q15,Q16 by the Kruskal-Wallis test. There were 45 people in the Recommendation entrance examination group, 48 people in the Admissions Office group, 10 people in the Achievement group, and 15 people in the Working people group.

After the analysis, there was no significant difference in all. And I classified the entrance examination method into two groups. There are "Admissions Office entrance examination group $(\mathrm{N}=48)$ ", "the other group $(\mathrm{N}=70)$. So analyzed between Admissions Office entrance examination group and the other group by Mann-Whitney's U test. As a result of the analysis, there was no significant difference in either group.

Table7. 【RQ3】 Is there a significant difference in the way to enter the university? $* * \mathrm{p}<0.01$, $* \mathrm{p}<0.05$ 


\begin{tabular}{|c|c|c|c|c|c|c|}
\hline & & $\begin{array}{c}\text { Recommendation } \\
\text { entrance } \\
\text { examination group }\end{array}$ & $\begin{array}{c}\text { Admissions Office } \\
\text { entrance } \\
\text { examination group }\end{array}$ & \begin{tabular}{|} 
Achievement \\
entrance \\
examination group
\end{tabular} & \begin{tabular}{|} 
Working people \\
entrance \\
examination group
\end{tabular} & \multirow[t]{2}{*}{$p$ value } \\
\hline & & \multicolumn{4}{|c|}{ average of the ranks } & \\
\hline \multirow{5}{*}{ Q7. How well were you satisfied? } & A.University & 62.700 & 61.719 & 42.250 & 54.300 & 0.2600 \\
\hline & B.Lesson & 56.589 & 59.865 & 56.850 & 68.833 & 0.6225 \\
\hline & C.Teacher & 55.989 & 60.583 & 71.250 & 58.733 & 0.5768 \\
\hline & D.Career support & 61.400 & 58.375 & 65.050 & 53.700 & 0.8012 \\
\hline & E.Facility & 61.578 & 62.458 & 56.000 & 46.133 & 0.3359 \\
\hline \multirow{6}{*}{$\begin{array}{l}\text { Q10. How useful was your Junior } \\
\text { College education? }\end{array}$} & A.Finding a satisfactory job & 62.867 & 57.583 & 62.000 & 53.867 & 0.7379 \\
\hline & B.Long-term career & 58.933 & 59.750 & 58.200 & 61.267 & 0.9937 \\
\hline & C.Human relationship building & 62.578 & 58.333 & 57.500 & 55.333 & 0.8526 \\
\hline & D.Family life & 59.356 & 61.250 & 53.500 & 58.333 & 0.9149 \\
\hline & E.Character formation & 56.455 & 62.479 & 65.700 & 50.867 & 0.4854 \\
\hline & F.Acquisition of Liberal Arts & 59.057 & 61.990 & 55.900 & 51.333 & 0.6766 \\
\hline $\begin{array}{l}\text { Q12. Did you consult with your } \\
\text { teacher about your work? }\end{array}$ & & 60.833 & 60.677 & 62.550 & 49.700 & 0.6357 \\
\hline $\begin{array}{l}\text { Q13. After Junior College } \\
\text { graduation, do you want to consult } \\
\text { with your teacher about your work? }\end{array}$ & & 55.311 & 61.032 & 73.700 & 53.900 & 0.3380 \\
\hline \multirow{6}{*}{$\begin{array}{l}\text { Q14. How much you needed to } \\
\text { learn following graduation? }\end{array}$} & A.Major field & 61.174 & 55.469 & 63.750 & 57.033 & 0.7728 \\
\hline & B.Another major field & 62.198 & 54.406 & 60.700 & 59.533 & 0.6810 \\
\hline & C.Liberal Arts & 57.942 & 54.011 & 65.000 & 66.000 & 0.5101 \\
\hline & D.work related & 57.616 & 58.323 & 71.700 & 52.800 & 0.4840 \\
\hline & E.Degree of Bachelor and Master & 55.360 & 62.625 & 60.000 & 53.300 & 0.6556 \\
\hline & F.Certification acquisition & 57.767 & 58.135 & 60.100 & 60.700 & 0.9885 \\
\hline \multirow{3}{*}{$\begin{array}{l}\text { Q15. After Junior College } \\
\text { graduation, do you want to } \\
\text { participate in these event? }\end{array}$} & A.University Festival & 63.909 & 56.021 & 59.650 & 53.700 & 0.5997 \\
\hline & B.Homecoming Day & 59.535 & 57.063 & 54.150 & 63.033 & 0.8722 \\
\hline & C.Extension lecture & 57.105 & 54.021 & 71.000 & 68.500 & 0.2271 \\
\hline $\begin{array}{l}\text { Q16. Did you participate in club } \\
\text { activities? }\end{array}$ & & 60.057 & 53.906 & 68.000 & 66.200 & 0.3697 \\
\hline
\end{tabular}

【RQ4】 Is there a significant difference between first choice and the other (Not first choice) about going $\mathrm{X}$ junior college?

In order to test RQ4, I classified two groups in Q6 (Did you consider another program before you decided to go to this junior college?). Students who entered junior college by first choice are referred as 『First choice group』. Students who didn’t enter junior college by first choice are referred as 『Not first choice group』.

I analyzed between First choice group and Not first choice group about in their answers to Q7,Q10,Q12,Q13,Q14,Q15,Q16 by Mann-Whitney's U test. There are 54 people in the First choice group and 66 people in the Not first choice group. First choice group are 54 people and Not first choice group are 66 people.

As a result of the analysis, there was no significant difference in either group.

Table8. 【RQ4】 Is there a significant difference between first choice and the other (Not first choice) about going $\mathrm{X}$ junior college? ${ }^{* *} \mathrm{p}<0.01,{ }^{*} \mathrm{p}<0.05$ 


\begin{tabular}{|c|c|c|c|c|c|}
\hline & & First choice group & $\begin{array}{l}\text { Not first choice } \\
\text { group }\end{array}$ & \multirow[t]{2}{*}{ Z-score } & \multirow[t]{2}{*}{$\mathrm{p}$ value } \\
\hline & & \multicolumn{2}{|c|}{ average of the ranks } & & \\
\hline \multirow{5}{*}{ Q7. How well were you satisfied? } & A.University & 63.241 & 58.258 & 0.8394 & 0.4012 \\
\hline & B.Lesson & 65.685 & 56.258 & 1.6028 & 0.1090 \\
\hline & C.Teacher & 60.417 & 60.568 & 0.0256 & 0.9796 \\
\hline & D.Career support & 59.306 & 61.477 & 0.3619 & 0.7174 \\
\hline & E.Facility & 59.213 & 61.553 & 0.3938 & 0.6937 \\
\hline \multirow{6}{*}{$\begin{array}{l}\text { Q10. How useful was your Junior } \\
\text { College education? }\end{array}$} & A.Finding a satisfactory job & 62.102 & 59.189 & 0.5012 & 0.6162 \\
\hline & B.Long-term career & 61.741 & 59.485 & 0.3865 & 0.6991 \\
\hline & C.Human relationship building & 61.370 & 59.788 & 0.2672 & 0.7893 \\
\hline & D.Family life & 60.870 & 60.197 & 0.1133 & 0.9098 \\
\hline & E.Character formation & 60.380 & 59.685 & 0.1212 & 0.9035 \\
\hline & F.Acquisition of Liberal Arts & 59.685 & 60.262 & 0.1017 & 0.9190 \\
\hline $\begin{array}{l}\text { Q12. Did you consult with your } \\
\text { teacher about your work? }\end{array}$ & & 57.463 & 62.985 & 0.9467 & 0.3438 \\
\hline $\begin{array}{l}\text { Q13. After Junior College } \\
\text { graduation, do you want to consult } \\
\text { with your teacher about your work? }\end{array}$ & & 58.750 & 61.038 & 0.3882 & 0.6979 \\
\hline \multirow{6}{*}{$\begin{array}{l}\text { Q14. How much you needed to } \\
\text { learn following graduation? }\end{array}$} & A.Major field & 58.722 & 60.156 & 0.2487 & 0.8036 \\
\hline & B.Another major field & 58.593 & 60.266 & 0.2854 & 0.7753 \\
\hline & C.Liberal Arts & 55.009 & 62.421 & 1.2753 & 0.2022 \\
\hline & D.work related & 55.574 & 62.813 & 1.2656 & 0.2057 \\
\hline & E.Degree of Bachelor and Master & 59.491 & 59.508 & 0.0028 & 0.9977 \\
\hline & F.Certification acquisition & 54.389 & 63.813 & 1.5781 & 0.1145 \\
\hline \multirow{3}{*}{$\begin{array}{l}\text { Q15. After Junior College } \\
\text { graduation, do you want to } \\
\text { participate in these event? }\end{array}$} & A.University Festival & 61.417 & 58.823 & 0.4321 & 0.6657 \\
\hline & B.Homecoming Day & 57.783 & 60.900 & 0.5476 & 0.5840 \\
\hline & C.Extension lecture & 56.292 & 62.115 & 1.0046 & 0.3151 \\
\hline $\begin{array}{l}\text { Q16. Did you participate in club } \\
\text { activities? }\end{array}$ & & 57.463 & 62.108 & 0.8187 & 0.4130 \\
\hline
\end{tabular}

【RQ5】 Is there a significant difference between students who participated in club activities and students who did not?

There are 4 choices at in "Q16.Did you participate in club activities?". In order to test RQ5, "very often" and "often" in Q16 are referred to as 『Club activities group』. " sometimes" and "never" are referred to as 『Not Club activities group』.

I analyzed between First choice group and Not first choice group in their answers to about Q7,Q10,Q13,Q14,Q15 by Mann-Whitney's U test. There are 33 people in the Club activities group and 78 people in the Not Club activities group.

The results of the analysis are described in Table 7. There was a significant difference in the Q10. Not Club activities group is higher than Club activities group. In detail, Not Club activities group is higher in their answers to "D. Family life $(\mathrm{p}<0.01)$ ","E. Character formation $(\mathrm{p}<$ 0.05）"in Q10.

Table9. 【RQ5】 Is there a significant difference between students who participated in club activities and students who did not? ${ }^{* *} \mathrm{p}<0.01,{ }^{*} \mathrm{p}<0.05$ 


\begin{tabular}{|c|c|c|c|c|c|c|}
\hline & & $\begin{array}{l}\text { Club activities } \\
\text { group }\end{array}$ & $\begin{array}{l}\text { Not Club } \\
\text { activities group }\end{array}$ & \multirow[t]{2}{*}{ Z-score } & \multirow[t]{2}{*}{$p$ value } & \\
\hline & & \multicolumn{2}{|c|}{ average of the ranks } & & & \\
\hline \multirow{5}{*}{ Q7. How well were you satisfied? } & A.University & 49.394 & 58.117 & 1.4086 & 0.1589 & \\
\hline & B.Lesson & 55.742 & 56.109 & 0.0594 & 0.9526 & \\
\hline & C.Teacher & 56.485 & 55.795 & 0.1115 & 0.9112 & \\
\hline & D.Career support & 55.909 & 56.038 & 0.0207 & 0.9835 & \\
\hline & E.Facility & 51.197 & 58.032 & 1.1050 & 0.2692 & \\
\hline \multirow{6}{*}{$\begin{array}{l}\text { Q10. How useful was your Junior } \\
\text { College education? }\end{array}$} & A.Finding a satisfactory job & 48.242 & 59.282 & 1.8193 & 0.0689 & \\
\hline & B.Long-term career & 56.788 & 55.667 & 0.1852 & 0.8531 & \\
\hline & C.Human relationship building & 49.364 & 58.808 & 1.5314 & 0.1257 & \\
\hline & D.Family life & 43.833 & 6147 & 2.7797 & 0.0054 & ** \\
\hline & E.Character formation & 47.258 & 5969 & 2.0653 & 0.0389 & $*$ \\
\hline & F.Acquisition of Liberal Arts & 51.939 & 57.718 & 0.9766 & 0.3287 & \\
\hline $\begin{array}{l}\text { Q12. Did you consult with your } \\
\text { teacher about your work? }\end{array}$ & & 51.591 & 57.865 & 1.0168 & 0.3092 & \\
\hline $\begin{array}{l}\text { Q13. After Junior College } \\
\text { graduation, do you want to consult } \\
\text { with your teacher about your work? }\end{array}$ & & 58.939 & 54.026 & 0.8004 & 0.4235 & \\
\hline \multirow{6}{*}{$\begin{array}{l}\text { Q14. How much you needed to } \\
\text { learn following graduation? }\end{array}$} & A.Major field & 61.727 & 52.831 & 1.4688 & 0.1419 & \\
\hline & B.Another major field & 57.333 & 54.714 & 0.4261 & 0.6700 & \\
\hline & C.Liberal Arts & 53.156 & 55.766 & 0.4245 & 0.6712 & \\
\hline & D.work related & 53.227 & 56.474 & 0.5429 & 0.5872 & \\
\hline & E.Degree of Bachelor and Master & 56.091 & 55.247 & 0.1323 & 0.8947 & \\
\hline & F.Certification acquisition & 58.121 & 54.377 & 0.5983 & 0.5497 & \\
\hline \multirow{3}{*}{$\begin{array}{l}\text { Q15. After Junior College } \\
\text { graduation, do you want to } \\
\text { participate in these event? }\end{array}$} & A.University Festival & 64.318 & 52.481 & 1.8759 & 0.0607 & \\
\hline & B.Homecoming Day & 62.318 & 52.578 & 1.6473 & 0.0995 & \\
\hline & C.Extension lecture & 57.242 & 54.753 & 0.4123 & 0.6801 & \\
\hline
\end{tabular}

\section{Conclusion}

In this study, the following three things became clear by analyzing the results of a survey conducted among the graduates of a Junior College in Japan. Firstly, there is a difference between students who ask for advice from teachers and students who do not. It was found that the former students have a higher expectation for the college and higher motivation. This result shows us that going to professors for advice gives students good effects improved on their school lives. Secondly, there is a difference between students who have any achieved certificates and students who do not. It was found that the former students think to keep pursue learning even after graduation. It is considered that those students are strongly aware of the necessity to pursue their future careers or the importance of learning by pursuing certificates. Thirdly, the method of entrance to the university does not make any difference to students. Perhaps this means the students who pursue their careers gain satisfaction from their school lives, and can keep learning after graduation.

Taking this study into account, I would like to be involved in the policy planning and execution related to management using statistical analysis in the future.

\section{References}

[1] Saupe.J.L,1990, The functions of institutional research 2nd ed, Association for Institutional Research

[2] Reiko Yamada, 2012, Gakushikatei kyoiku no Shitsuhosho he mukete [Quality assurance of undergraduate education], TOSHINDO PUBLISHING CO.,LTD 
[3] Toshinori Kawamata, 2009, Graduates who do not feel attachment in their almar mater : Grand total of the Suzuka junior college graduate investigation, Suzuka Junior Colleage Journal 29, pp.1-27

\section{Questionnaire}

$\begin{array}{llllllll}\text { Q 1 . gender } 1 \text { female } & 2 \text { male } & \text { Q 2 } & \text { major } & {[} \\ \text { Q 3 . Are you expected to graduate in March? } & 1 & \text { yes } & 2 & \text { No }\end{array}$

Q 4. What was your entrance method? Please mark in the appropriate item
1 Recommendation entrance examination
2 Admissions Office entrance examination
3 Achievement entrance examination 4 Working people entrance examination
5 others [

Q 5. Why did you go to university? Please mark in the appropriate item.

\begin{tabular}{|c|c|c|c|c|}
\hline 1 & There was a major I wanted to learn & 2 & take certifications & \\
\hline 3 & finding employment & 4 & school spirit & \\
\hline 5 & attending school & 6 & $\begin{array}{l}\text { recommendation of high } \\
\text { teacher }\end{array}$ & school \\
\hline 7 & recommendation of parent & 8 & recommendation of friends & \\
\hline 9 & academic achievement & 10 & economic reasons & \\
\hline $\begin{array}{l}11 \\
13\end{array}$ & $\begin{array}{l}\text { I did not go to the school I want to go to } \\
\text { others [ }\end{array}$ & 12 & education philosophy & ] \\
\hline
\end{tabular}

Q6. Did you think of another school before you decided to go to this junior college? Please mark in the appropriate item.

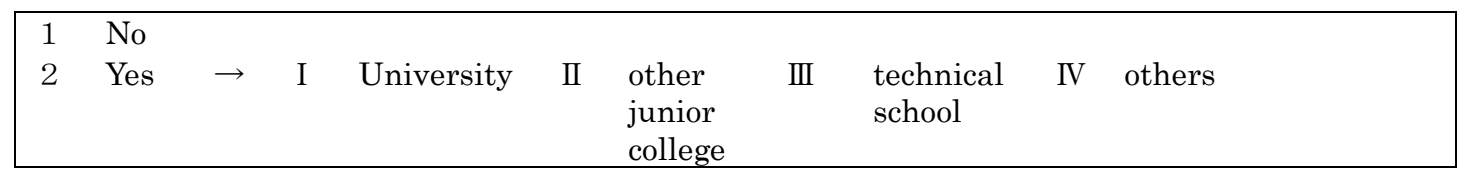

Q 7. How well were you satisfied? Please mark in the appropriate item.

\begin{tabular}{|l|l|c|c|c|c|c|}
\hline \multicolumn{2}{|l|}{} & $\begin{array}{c}\text { Very satis- } \\
\text { fied }\end{array}$ & $\begin{array}{c}\text { Quite a sat- } \\
\text { isfied }\end{array}$ & ordinary & $\begin{array}{c}\text { Little sat- } \\
\text { isfied }\end{array}$ & $\begin{array}{c}\text { Never sat- } \\
\text { isfied }\end{array}$ \\
\hline A & University & 5 & 4 & 3 & 2 & 1 \\
\hline B & Lesson & 5 & 4 & 3 & 2 & 1 \\
\hline C & Teacher & 5 & 4 & 3 & 2 & 1 \\
\hline D & Career support & 5 & 4 & 3 & 2 & 1 \\
\hline E & Facility & 5 & 4 & 3 & 2 & 1 \\
\hline
\end{tabular}

Q 8. Who was responsible for tuition and living expenses? Please mark in the appropriate item.

\begin{tabular}{|l|l|r|r|r|c|}
\hline \multicolumn{2}{|l|}{} & ALL & $\begin{array}{l}\text { Most } \\
\text { part }\end{array}$ & little & Nothing \\
\hline A & family and relatives & 4 & 3 & 2 & 1 \\
\hline B & part-time job and savings & 4 & 3 & 2 & 1 \\
\hline C & scholarship & 4 & 3 & 2 & 1 \\
\hline D & others [ & 4 & 3 & 2 & 1 \\
\hline
\end{tabular}

Q 9. What certifications did you get? Please mark in the appropriate item.

\begin{tabular}{|c|c|c|c|c|c|c|c|}
\hline 1 & Nutritionist, & 2 & $\begin{array}{l}\text { Nutrition } \\
\text { teacher }\end{array}$ & 3 & $\begin{array}{l}\text { Home cooking skills } \\
\text { test }\end{array}$ & 4 & $\begin{array}{l}\text { Nutritionist placement } \\
\text { test }\end{array}$ \\
\hline 5 & School nurse & 6 & Home Helper & 7 & $\begin{array}{l}\text { Red Cross first-aid } \\
\text { Rescuer }\end{array}$ & 8 & Social welfare director \\
\hline
\end{tabular}




$\left.\begin{array}{|llllllll}9 & \text { Nursery teacher } & 10 & \begin{array}{l}\text { Kindergar- } \\ \text { ten teacher }\end{array} & 11 & \begin{array}{l}\text { Recreation Instruc- } \\ \text { tor }\end{array} & 12 & \begin{array}{l}\text { Information } \\ \text { Test }\end{array} \\ 13 & \text { Music therapy } & 14 & \begin{array}{l}\text { Medical of- } \\ \text { fice work }\end{array} & 15 & \text { Peer Helper } & 16 & \text { Eating habits Advisor } \\ 17 & \text { others [ } & & & & \end{array}\right]$

Q1 0. How useful was your Junior College education? Please mark in the appropriate item.

\begin{tabular}{|l|l|c|c|c|c|c|}
\hline \multicolumn{2}{|l|}{} & $\begin{array}{c}\text { Very use- } \\
\text { ful }\end{array}$ & $\begin{array}{c}\text { Quite a } \\
\text { useful }\end{array}$ & ordinary & $\begin{array}{c}\text { Little } \\
\text { useful }\end{array}$ & $\begin{array}{c}\text { Never } \\
\text { useful }\end{array}$ \\
\hline A & Finding a satisfactory job & 5 & 4 & 3 & 2 & 1 \\
\hline B & Long-term career & 5 & 4 & 3 & 2 & 1 \\
\hline C & Human relationship building & 5 & 4 & 3 & 2 & 1 \\
\hline D & Family life & 5 & 4 & 3 & 2 & 1 \\
\hline E & Character formation & 5 & 4 & 3 & 2 & 1 \\
\hline F & Acquisition of Liberal Arts & 5 & 4 & 3 & 2 & 1 \\
\hline
\end{tabular}

Q 1 1. What is your career after graduation? Please mark in the appropriate item.

\begin{tabular}{|llll|}
\hline 1 & Full-time employee & 2 & Self employed \\
3 & Contract employee & 4 & Go to university \\
5 & Go to technical school & 6 & Part time job \\
7 & Job hunting & 8 & Housework \\
9 & others [ & & \\
\hline
\end{tabular}

Q 12 . Did you consult with your teacher about your work? Please mark in the appropriate item.

\begin{tabular}{|c|c|c|c|c|}
\hline 5 & 4 & 3 & 2 & 1 \\
\hline Very often & often & ordinary & sometimes & Never \\
\hline
\end{tabular}

Q 1 3. After Junior College graduation, do you want to consult with your teacher about your work? Please mark in the appropriate item.

\begin{tabular}{|c|c|c|c|c|}
\hline 5 & 4 & 3 & 2 & 1 \\
\hline Very often & often & ordinary & sometimes & Never \\
\hline
\end{tabular}

Q 14 . How much you needed to learn following graduation? Please mark in the appropriate item.

\begin{tabular}{|l|l|c|c|c|c|c|}
\hline \multicolumn{2}{|l|}{} & $\begin{array}{c}\text { Very } \\
\text { need }\end{array}$ & $\begin{array}{c}\text { Quite a } \\
\text { need }\end{array}$ & ordinary & $\begin{array}{c}\text { Little } \\
\text { need }\end{array}$ & $\begin{array}{c}\text { Never } \\
\text { need }\end{array}$ \\
\hline A & Major field & 5 & 4 & 3 & 2 & 1 \\
\hline B & Another major field & 5 & 4 & 3 & 2 & 1 \\
\hline C & Liberal Arts & 5 & 4 & 3 & 2 & 1 \\
\hline D & work related & 5 & 4 & 3 & 2 & 1 \\
\hline E & Degree of Bachelor and Master & 5 & 4 & 3 & 2 & 1 \\
\hline F & Certification acquisition & 5 & 4 & 3 & 2 & 1 \\
\hline
\end{tabular}

Q1 5. After Junior College graduation, do you want to participate in these event? Please mark in the appropriate item.

\begin{tabular}{|c|l|c|c|c|c|c|}
\hline \multicolumn{2}{|l|}{} & $\begin{array}{c}\text { Very of- } \\
\text { ten }\end{array}$ & often & ordinary & sometimes & Never \\
\hline A & University Festival & 5 & 4 & 3 & 2 & 1 \\
\hline B & Homecoming Day & 5 & 4 & 3 & 2 & 1 \\
\hline C & Extension lecture & 5 & 4 & 3 & 2 & 1 \\
\hline
\end{tabular}

Q 1 6. Did you participate in club activities? Please mark in the appropriate item.

\begin{tabular}{|c|c|c|c|c|}
\hline 5 & 4 & 3 & 2 & 1 \\
\hline Very often & often & ordinary & sometimes & Never \\
\hline
\end{tabular}

